Article

\title{
Sustainability-Conscious Stakeholders and CSR: Evidence from IJVs of Ghana
}

\author{
Gang Tian ${ }^{1}$, Gabriel Dodzi Pekyi ${ }^{1}$, Haojia Chen ${ }^{2, *}$, Huaping Sun ${ }^{3, * \mathbb{C}}$ and Xiaoling Wang ${ }^{4}$ \\ 1 School of Management, Jiangsu University, Zhenjiang 212013, China; 1000003856@ujs.edu.cn (G.T.); \\ 5102180219@stmail.ujs.edu.cn or gabriella@ajaic.org (G.D.P.) \\ 2 Warwick Manufacturing Group (WMG), University of Warwick, Coventry CV4 7AL, UK \\ 3 School of Finance \& Economics, Jiangsu University, Zhenjiang 212013, China \\ 4 College of Philosophy, Law \& Political Science, Shanghai Normal University, Shanghai 200234, China; \\ wangxiaoling@shnu.edu.cn \\ * Correspondence: Haojia.chen@warwick.ac.uk (H.C.); shp@ujs.edu.cn (H.S.)
}

Citation: Tian, G.; Pekyi, G.D.; Chen

H.; Sun, H.; Wang, X.

Sustainability-Conscious

Stakeholders and CSR: Evidence from IJVs of Ghana. Sustainability 2021, 13,

639. https://doi.org/10.3390/

su13020639

Received: 29 November 2020

Accepted: 31 December 2020

Published: 11 January 2021

Publisher's Note: MDPI stays neutral with regard to jurisdictional clai$\mathrm{ms}$ in published maps and institutional affiliations.

Copyright: $\odot 2021$ by the authors. Licensee MDPI, Basel, Switzerland. This article is an open access article distributed under the terms and conditions of the Creative Commons Attribution (CC BY) license (https:// creativecommons.org/licenses/by/ $4.0 /)$.

\begin{abstract}
Corporate social responsibility (CSR) activities of international joint ventures (IJVs) are considered a way for multinational corporations (MNCs) to be embedded in local communities. Existing literature generally assumes that MNC research applies to IJV, however, the research of IJV's CSR practices is often ignored. In particular, it is unclear which stakeholders become important factors in influencing the CSR practices of IJVs in developing countries. This paper aims to examine the structural characteristics of IJVs and propose a framework for the CSR practice of IJVs established in Ghana. The theoretical standpoint of this research is built upon the stakeholder and institutional theories. Using stepwise regression, a framework is developed to better understand and identify the forces within the local market that stimulate CSR. Consumers, competitors, and local communities are considered to be the key stakeholders driving IJV CSR actions. In addition, this paper has identified significant differences in CSR practice related to the IJV's ownership structure. This study contributes to the literature on furthering knowledge of CSR and IJVs. Furthermore, it also provides practical implications for MNCs to better integrate into the local market and the host country in order to promote the development of stakeholders related to IJVs.
\end{abstract}

Keywords: corporate social responsibility; stakeholder; international joint ventures; Ghana

\section{Introduction}

In an organization's aspirations to internationalize, international joint ventures (IJVs) are considered pivotal and are therefore seen as a more preferable alternative in seeking ways to expand foreign markets [1]. Multinational corporations (MNCs) have engaged in the usage of IJVs as a strategic alternative to successfully enter foreign markets by means of a more cooperative strategy in order to partially deal with the liability of foreignness faced within new markets [2,3]. The incorporation of stakeholders from the home and host markets often requires paying close attention to the local activities of MNCs as a result of reports on corrupt dealings, unacceptable conducts, and other factors [4]. Failure to do so potentially results in further complex and vocal reactions to the behaviors of firms both locally and internationally.

For similar reasons, stakeholders and researchers have adopted corporate social responsibility (CSR) as a means of establishing the ethical practices and responsibilities of firms that operate in foreign markets $[5,6]$. The research on CSR has received much focus and has expanded over the past few years. It has progressed from a basic study of ethical behavior in foreign environments, to an evaluation of the means to yielding positive influences in the local environment. Eventually, this adds to the development of the local economy by enhancing the standard of living of the labor force, community members, and the society as a whole [7]. According to Galbreath [8], IJVs and CSR are suggested 
ways by which firms can become rooted in the local community or reduce undesirable views towards foreign firms. As stakeholder expectations of organizations to undertake CSR grow, foreign members of the IJVs should pay close attention to what engenders the implementation of local CSR practices. Nonetheless, in the case of an IJV, stakeholders that influence management decisions to adopt CSR practices are not apparent.

Existing research on CSR practices of multinational companies in host countries focuses on large developing countries such as China and other emerging markets. There is a general lack of focus on African countries such as Ghana [9]. The literature on joint ventures in Ghana focuses on the formation and requirements of joint ventures and their capital structure, ignoring the research on CSR practice of joint ventures [10,11]. In fact, Ghana is among the fastest growing economies in Africa. Over the past decade, Ghana has had enormous Foreign Direct Investment (FDI) flowing into the country as a result of gaining the attention of large MNCs, especially from developed countries. This has been achieved through the introduction of the Ghana Investment Promotion Centre which has promoted and facilitated investment activities in the country. The favorable regulations concerning joint relationships with local firms have seen an increase in the creation of IJVs between foreign and local firms. As a developing country, Ghana is witnessing active strong collaborative relationships among both foreign and local organizations in the market. Ghana is also going through ethical management and CSR transformation processes. Therefore, there is a research gap, and we need to pay closer attention to the CSR practices of multinational companies in African countries (such as Ghana) that have active economies and a growing foreign interchange.

On the other hand, the existing literature on CRS practice mainly focused on the activities of MNCs and their subsidiaries [12,13]. The CRS practice of joint ventures has not been considered as a potential area of study. This is due to the ostensible supposition that studies on MNCs apply to IJVs as well. This also reveals a gap in the existing literature. In fact, a joint venture has a unique organizational structure [4], and the CSR orientation involved may be different from that of a wholly owned subsidiary of a multinational company. Hence, existing research assumes that CSR practices based on MNC are also applicable to IJV, ignoring the differences caused by its structure and operation. Therefore, it is necessary to further examine the CSR practices of MNCs' joint ventures in Ghana, which are economically active in African countries, in order to determine the special issues related to them.

To bridge the gaps identified, we seek to answer the following research question: which stakeholders have positive impacts on an IJV's pursuit of CSR activities in Ghana? Investigating the influence of various stakeholders and the interaction among them helps MNCs to identify and understand the drivers of CSR for IJVs when venturing into new market environments such as Ghana. This study adds to existing literature on CSR as it gives a vivid evaluation of the impact of each stakeholder group in the IJV. Also, unlike others, our research is unique as it focuses on Ghana, a West African country with an active economy and a growing foreign interchange. Furthermore, this paper seeks to examine how the ownership structure of the IJV affects its pursuit of CSR. We compare IJV against wholly owned subsidiaries (WOSs) and attempt to determine whether there is a difference in the pursuit of CSR between the two types of companies. Using analysis of variance (ANOVA) techniques and regressions, we discovered that pressure from stakeholders drove CSR engagement. Notably, we found out that consumers, competitors, and the local community are influential stakeholders in stimulating CSR in IJVs. We also discovered that given the various ownership types of an IJV, the IJV with foreign dominant ownership would be a channel leading to good corporate citizenship. On the other hand, we found that when subsidiaries finally become WOS, they seem to focus more on acting responsibly and ethically so as to gain legitimacy in the market and establish stronger local relationships.

To achieve the objectives of this study, the structure will consist of the following parts: The next section presents a literature review on CSR and the stakeholder theory, and then the study will discuss the hypotheses. This is then followed by an outline of the 
methodology, then a presentation of the findings. This study will proceed to discuss the findings and then conclude with a summary and point out the managerial implications of the study.

\section{Theoretical Background}

Organizations do not operate in a vacuum. In the course of operation, they interact with various entities, which either impact their actions or are impacted by their activities. These entities are termed as stakeholders. Freeman [14] (p. 46) developed the stakeholder theory, he defined stakeholder as "any group or individual that may influence or be affected by the realization of organizational goals." Over the past few decades, many researchers have conducted extensive research based on Freeman's views. According to the stakeholder theory, the continuity and stability of an organization is largely dependent on its capacity to create wealth, value, or satisfaction for its stakeholders $[15,16]$. The entities whose interaction with the organization are critical to and directly affect the fulfilment of its mission are referred to as primary stakeholders. They possibly include (1) local government, (2) investors, (3) suppliers, (4) internal managers and employees, and (5) consumers $[16,17]$. On the other hand, secondary stakeholders constitute those political and social agents who aid the organization in pursuing its mission through their endorsement of business operations. They perhaps include (1) local community, (2) local media, (3) nongovernmental organizations (NGOs), and (4) competitors [16,18].

The underlying concept of the stakeholder theory is that organizations produce externalities which impact various stakeholder groups. According to Sarkis et al. [19], these externalities account for the stakeholder pressures that organizations face. These pressures are exerted to reduce the negative impacts and increase those that are positive. Likewise, multinational enterprises face perpetual pressures from local government, non-governmental organizations, employees, and local community groups. This in turn necessitates the incorporation of their concerns and demands into organizational strategies and pursuits, allowing the MNCs' subsidiaries, particularly IJVs, to effectively carry out their business activities in the foreign market. Through foreign direct investment (FDI), MNCs venture into foreign markets, and unlike local firms, their relationship with stakeholders is essential for the subsidiary, especially the foreign parent of the IJV to surmount the institutional dilemmas it suffers in the foreign market [20].

Institutions are surrounded by systems which influence organizational activities and their behavior towards society [21]. There are institutional environments; firms need to conform to in their pursuit of gaining social acceptability and legitimacy [22]. Institutional theory suggests that there are three categories of institutional isomorphic changes [23]. These are (I) coercive isomorphism, caused by pressure applied by influential firms, (II) mimetic isomorphism, caused by uncertainties in the environment which push firms to emulate other successful competitors in the same industry, and (III) normative isomorphism, as a result of professionalization. Scott [21] further extended the three aspects into regulatory, cognitive, and normative domains. To apply the aforementioned viewpoints to the field of international business, multinational corporations may be required to conform to institutional factors in order to minimize uncertainty and ambiguity in the local market. The decision-making process of MNCs needs to pay greater attention to the institutional variations, in terms of the regulatory, normative, and cognitive domains, between the host and home countries. Campbell et al. [24] suggests that the larger the distance between the host and home countries, the organization will suffer more liabilities of foreignness (for example, unfamiliarity and discrimination risk in the foreign market), leading to an increase in their need to obtain legitimacy in the local market. According to the authors of Reference [25], MNCs especially encounter a number of hardships proceeding from the implication of normative and cognitive institutions. For firms to surmount these hardships, they will need to adopt CSR practices which have proved to be an effective means of overcoming the institutional distance $[13,26]$. 
Similarly, the foreign entrants' structures and CSR practices are generally affected by the institutional processes emanating from pressure from influential local entities. These interactions include relations with other local firms in the foreign market, the expertise of internal members and their perspective of CSR, and the value and tendency of local community members [27], all of which encompasses local stakeholders' expectations. Hence, CSR management and direction must be distinguished according to each foreign market and the various stakeholder demands. Local legitimacy and stakeholders' acceptance may be obtained by foreign entrants through the adaptation of their CSR policies and structures subject to the prevalent conditions in each environment. Local legitimacy is important for the sustenance of a business and is gained by conforming to the belief systems and principles of local stakeholder groups [28]. Following this line of reasoning, there is a strong link between stakeholders' demands and institutional pressures [28,29], therefore foreign entrants need to engage in proactive stakeholder dialogues in order to successfully execute CSR and thus become entrenched in host economies.

According to Udayasankar [30], CSR engagement is customarily inspired by the various demands of stakeholders. In line with the development of the stakeholder approach, the authors of Reference [31] suggest that the restructuring of CSR from a stakeholder's viewpoint opens up new ways of evaluating CSR. The majority of organizations, inclusive of MNCs, operate by intending to create high value for shareholders by conducting activities that maximize profits. Nonetheless, firms who want to create corporate value are often obliged to acknowledge the views of other interest groups on ethical matters and pursue socially responsible activities. In this way, it will transcend legal and economic requirements in the environment where they operate. This particularly holds true for IJVs in that control and leadership sharing structures allow for stakeholder effects to be varied, which transcends a WOS as regards direct engagements within the local environment. Therefore, MNCs may incline, but for IJVs, require taking on philanthropic or ethical obligations towards each stakeholder in host countries and expecting to be society-oriented, undertaking voluntary activities to enhance the general welfare of the local community [32].

\section{Hypotheses Development}

\subsection{Primary Stakeholders}

\subsubsection{Consumers}

The most well-known and important stakeholders of any organization are the consumers since they are a major reason why firms exist in the first place. Consumers have increasingly become more than just numbers in the market. Customer satisfaction, as a result of consumers' access to vast data banks and instant information, has extended past concerns of price and quality into ethical practices of firms [33]. When consumers perceive that a company is acting unethically, they can apply pressure through either private or public channels, causing the company to modify their strategies to incorporate their concerns. According to Laczniak and Murphy [34], in an organization's efforts to manage the potential pressure, the organization tries to forecast and reduce the demand of consumers for it to behave responsibly and ethically in the market.

It is important to note that consumers, aside from the pressure they exert, develop positive perceptions for the products being offered by firms that practice CSR [31]. These positive perceptions create consumer goodwill, which also lead to an increase in buying incentives and increased profits. Therefore, modifying organizational policies and strategies in order to build good consumer relations is a step in the right direction. This is beneficial to the IJV as well as the foreign parent as it decreases the liabilities of foreignness faced by the foreign parent. Furthermore, it promotes a good image of the firm and repositions the organization in the mind of consumers. These discussions show how relevant consumers' values and perceptions are to IJVs and how they respond to them through socially responsible actions. Therefore, we posit: 
Hypothesis 1 (H1). Consumers are relevant stakeholder groups that have positive impacts on how IJVs pursue CSR activities in a foreign market.

\subsubsection{IJV Managers and Employees}

Among key stakeholders that influence the CSR practices of MNCs are internal managers and employees. Managers have direct participation in the decision making of organizations as they determine the organizational focus, policies, and strategies. Additionally, they set out the organization's ethical codes as well as assist in influencing the activities the organization chooses to undertake [31]. According to Hartman et al. [35], policies and procedures that are ethically based can aid in attracting and retaining high-quality and valuable employees as well sustaining company morale. This implies that the concept of CSR is a critical reputational element which substantially impacts the attractiveness of the organization to prospective and present employees [33]. An organization's internal CSR programs which are mostly towards its employees [36] and the organization's ethical reputation can aid in creating a positive relationship with its employees that may further help in the retention rate of employees and performance and increase firm value [37]. Various surveys have shown that when employees perceive that the organization where they work has carried out the requisite CSR; they develop a greater sense of identification with and trust towards the organization, which is vital for an organization in achieving its goals [38].

According to Greening and Gray [39], as managers represent an organization's decision-making body, they directly participate in the identification of problems, stakeholder expectations, and in the adoption and application of CSR measures. In an organization's pursuit of an agenda that is socially responsible, establishing harmony between organizational goals and the need to behave ethically requires managers' deliberate, systematic, and planned actions. As an IJV brings together managers from the parent firms, the association and coordination between them is critical because they will come into the IJV with their own aspirations and desires. Also, the orientation of managers towards CSR could potentially influence the direction of activities that the subsidiary will undertake. From these discussions, we, therefore, posit that:

Hypothesis 2 (H2). IJV managers and employees are a relevant stakeholder group that has positive impacts on how IJVs pursue CSR activities in a foreign market.

\subsubsection{Government}

Government is an important primary stakeholder as they constitute the highest authority in setting requirements for CSR and economy-based legislations. As governments react to local interests, they formulate statutes and regulations that express their citizens' needs, paving the way for growth. As governments implement the basic standards of operation for firms, they place themselves in the position as the primary stakeholder, which must be recognized and followed whist doing business within the market where they have control or power [40]. According to Detomasi [41], the established political direction and the interrelationship between the firm and government may potentially result in improved assistance. This then creates a higher measure of local legitimacy and enhanced relationship engendering probable decrease in the liability of foreignness experienced by the firm. As firms strive to be treated favorably by local government, as well as being recognized by ethical organizations, they seek to meet the requirements of government and create a positive impact on a local level [42]. Likewise, IJVs, whist having lesser power compared to MNCs, still need to meet the local government's political requirements in their endeavor to gain more legitimacy. Some level of local legitimacy is being established by the local parent company; however, the relationship established with the government would also influence the IJV's pursuit of CSR strategies. 
Hypothesis 3 (H3). Government is relevant stakeholder groups that have positive impacts on how IJVs pursue CSR activities in a foreign market.

\subsubsection{Suppliers}

Suppliers are essential to a firm's economic processes, and therefore it is highly relevant to establishing and maintaining a good relationship with them. Chen and Ahmad [43] highlight that CSR in the view of suppliers is linked to legal issues of local labor or environmental protection laws. They also highlight that in the case where the activities of subsidiaries breach these laws, subsidiaries may be unable to create or sustain working relationships with the supplier. When organizations pursue CSR, they create a desirable presence and gain importance as the expectations for the organization continue to grow. Furthermore, this impacts the organization's activities as well as their business associates within the whole supply chain. According to Faisal [44], the reputation and performance of a unit in the economic chain can have an effect on the other units within the chain due to the interrelationships among them.

For IJVs, mostly the foreign parents get involved with the supply network of the local parent and need to consider the expectations and concerns of the supply-chain. As they endeavor to establish higher standards or meet CSR initiatives which involve sourcing guarantees or international standards, suppliers tend to be in the category of key stakeholders in attaining these goals [45]. Studies by Zhang et al. [46] reveal that impressing local suppliers creates good image and benefits the firm in the form of augmented creditworthiness. Finally, in contrast with MNCs, which normally possess strong bargaining powers, IJVs mostly do not possess such powers needed to pressurize suppliers, but rather are more likely to respond to suppliers' expectations. Therefore, we posit that:

Hypothesis 4 (H4). Suppliers are relevant stakeholder groups that have positive impacts on how IJVs pursue CSR activities in a foreign market.

\subsubsection{Investors}

Investors are essential to a firm's capital generation and expansion aspirations. According to Angel and Rivoli [47], investors' influence is progressively gaining importance due to the emergence of investors who are mindful of society and also due to their influence on an institution's cost of equity capital. Investors who behave ethically are not attracted to or do not invest in organizations which are not environmentally responsible. According to Adam and Shavit [48], investments classified as socially responsible are regarded as equivalent to a mandatory act instead of an alternative, as they minimize the risk associated with long-term investment because of the nature of CSR activities. O'Shaughnessy et al. [49] suggest that the conception of socially responsible firms results in a higher sense of security in terms of cash flow, which makes these firms more appealing to invest in.

In an attempt for IJVs to find prospective investors, how socially responsible the IJVs are can be a point of great attraction and may project positive images about the firm. An investment's effect cannot be underrated because it is an important factor in determining the IJV's financial potential and continuity of operation [34]. In the establishment of an IJV, the current investors of one parent firm may come on board with formerly approved arrangements concerning CSR, which they expect to be incorporated in the firm's operations. Based on these, we postulate that:

Hypothesis 5 (H5). Investors are relevant stakeholders group that have positive impacts on how IJVs pursue CSR activities in a foreign market. 


\subsection{Secondary Stakeholders}

3.2.1. Competitors

Among the secondary stakeholders that influence the behavior of organizations are competitors. Competitors can help joint ventures to achieve institutional isomorphism through CSR practices in order to pursue social recognition and legitimacy. Thus, the minimum organizations have to do is to meet present competitors' CSR standards. Generally speaking, organizations will try to lead by example with regards to CSR engagement by maximizing competitive advantage whilst minimizing liability of foreignness [50]. According to Bondy et al. [51], considering competitors' performance to measure your own company's organizational performance is a conventional practice and is employed in the assessment of CSR practices. As an organization closely monitors adjustments and alterations in the competition, it is able to better define its own choices in the market.

IJVs must ensure they keep up with the competition within the local market in order to avoid possible loss in market share. It is imperative for the firm to be perpetually aware of its actions as well as those of its competitors, because competitors may leverage on possible shortcomings of the firm [52]. Therefore, the pressure of competition will force IJVs to improve organizational effectiveness and adaptability by strengthening corporate social responsibility practices. In addition, since the markets in which IJV are located are often uncertain, checking the behavior of competitors is an integral part of the normal operating system [53]. Therefore, we posit that:

Hypothesis 6 (H6). Competitors are relevant stakeholder groups that have positive impacts on how IJVs pursue CSR activities in a foreign market.

\subsubsection{Media}

Media represents an important stakeholder as it can control public opinion, particularly when it pertains to events regarding an organization. When the media exposes an organization's unethical behavior, it mostly leads to extensive attacks on commercialism, profiteering enterprise, as well as the company headquarters' inadequate performance of CSR. Media provides the public a means to obtain more insights about an organization and defines the outlook of businesses by way of uncovering inadequacies, controlling the views of the public, and calling for organizations to take on the implementation of local measures [54]. The media is an essential player for an organization considering its capability to spread information about ethical issues on how quickly and far such information reaches [55]. Since multinational corporations adopt IJVs as strategies to enter foreign markets so as to acquire useful market information and insights [56], the media may become an obstruction to future expansion. In the event an IJV falls into severe media scrutiny as a result of negative reports, it may in affect impede the MNC's plans to enter on a large-scale. Having transparent engagement with the local media can curb the spread of negative information about the organization and possibly make CSR initiatives of a firm reach a wider audience. With these discussions, we can infer that the media can greatly affect the corporate image, brand perceptions, and others of an organization, and therefore, we hypothesize that:

Hypothesis 7 (H7). The Media is a relevant stakeholder group that has positive impacts on how IJVs pursue CSR activities in a foreign market.

\subsubsection{Local Community}

In every society, ethical values and standards are established by the local people which every member must abide by. Aside from observing the activities of firms and ensuring these firms adapt to local standards, the local community allows firms the entitlement to conduct business [57]. Ignoring local community concerns may awaken intense reactions which can supersede a manager's or owner's principles and interests [58]. Also, with the 
IJV, there's a possibility that the local partner may have important associations within the local community causing them to be ingrained in the community's ideals and principles. As a result, the foreign partner is expected to conform to these circumstances and try to engage with the community in a bid to be rooted in the local community.

Promoting an IJV's image in the society can yield dividends by enhancing ethical practices resulting in gains as to prospective success and firm performance [31]. The basic purpose of adopting CSR measures by foreign subsidiaries was to establish deeper connections with the local community [59]. According to Waddock and Graves [60], working closely together with the local community strengthens the relationship, leading to outcomes such as local tax cuts, better performance of employees, and possibly lesser regulatory requirements. Finally, trust is established through direct engagement with the community, which potentially reduces the firm's foreignness in the local community. We, therefore, hypothesize that:

Hypothesis $\mathbf{8}$ (H8). The local community is a relevant stakeholder group that has positive impacts on how IJVs pursue CSR activities in a foreign market.

\subsubsection{Non-Governmental Organizations (NGOs)}

Economies are becoming more and more global and there continues to be a reduction or elimination of barriers, making room for multinational enterprises to move across nations on a large scale. There is a real need to enforce international standards to check for any possible irresponsible behavior [61]. Non-governmental organizations (NGOs), on their own volition, take up roles to additionally scrutinize the movement of MNCs across borders and pressurize these entities to adhere to international standards and to adapt their strategies and policies where needed [62]. According to Imbun [63], the relevance of NGOs and their campaigns have risen as a result of ethics and the supervision of firms across nations which have warranted a strategic movement for ethical management and sustainability. Though NGOs give more attention to MNCs, IJVs do not just stay away from the affair. IJVs also must regard the pressure from NGOs exerted via open conferences, studies, or reports which outlines their practices, sometimes including irresponsible conduct. Recognizing the importance of NGOs, we put forth that:

Hypothesis 9 (H9). NGOs are relevant stakeholder groups that have positive impacts on how IJVs pursue CSR activities in a foreign market.

\subsection{Structure of Ownership}

The focus of IJV literature has constantly been on the level of control, being shared partnership or dominant partner, as a factor resulting in various outcomes [56]. The establishment of IJVs creates a platform for cooperation between the two partners, allowing them to jointly pursue diverse objectives and targets while subsequently providing significant insights into cultural conflicts and control mechanisms [64]. Additionally, these diverse goals, objectives, and strategies become somewhat relevant in terms of dominant partner characteristics or joint ownership, considering the IJV's structure and interaction between parents [65]. This relationship must be demonstrated in the IJV's level of CSR activities because generally speaking, it is often believed that the foreign partner is a CSR adherent and will establish meaningful contact with the local market to curb its foreignness in the market.

Generally, WOSs explicitly represent MNC in foreign markets and this warrants augmented attention to CSR alternatives and to how ethically they operate. This does not exclude IJVs as they still have local responsibilities. The foreign parent continues to experience pressure from its home market to undertake CSR activities, to maintain positive recognition internationally and locally, and to curtail possible adverse consequences in a foreign market. On the contrary, the local parent may not be too bothered about the positive image linked with CSR, and for that matter, be less likely to engage in CSR. Instead, 
they may pursue related concerns that are knowledge-driven or seek to acquire technology. Therefore, it is expected that IJVs dominated by foreign control in comparison with the other ownership structures will demonstrate greater levels of CSR. Also, it is expected that the wholly owned subsidiaries will show greater levels of CSR in comparison to IJVs.

Hypothesis 10 (H10). The foreign parent majority ownership type will demonstrate greater levels of CSR in comparison to the 50/50 shared ownership type, sequentially demonstrating greater CSR levels than the local parent majority ownership type.

Hypothesis 11 (H11). Wholly owned subsidiaries will demonstrate higher levels of CSR as compare to IJVs.

Based the above Hypotheses, we provide the conceptual framework (Figure 1).

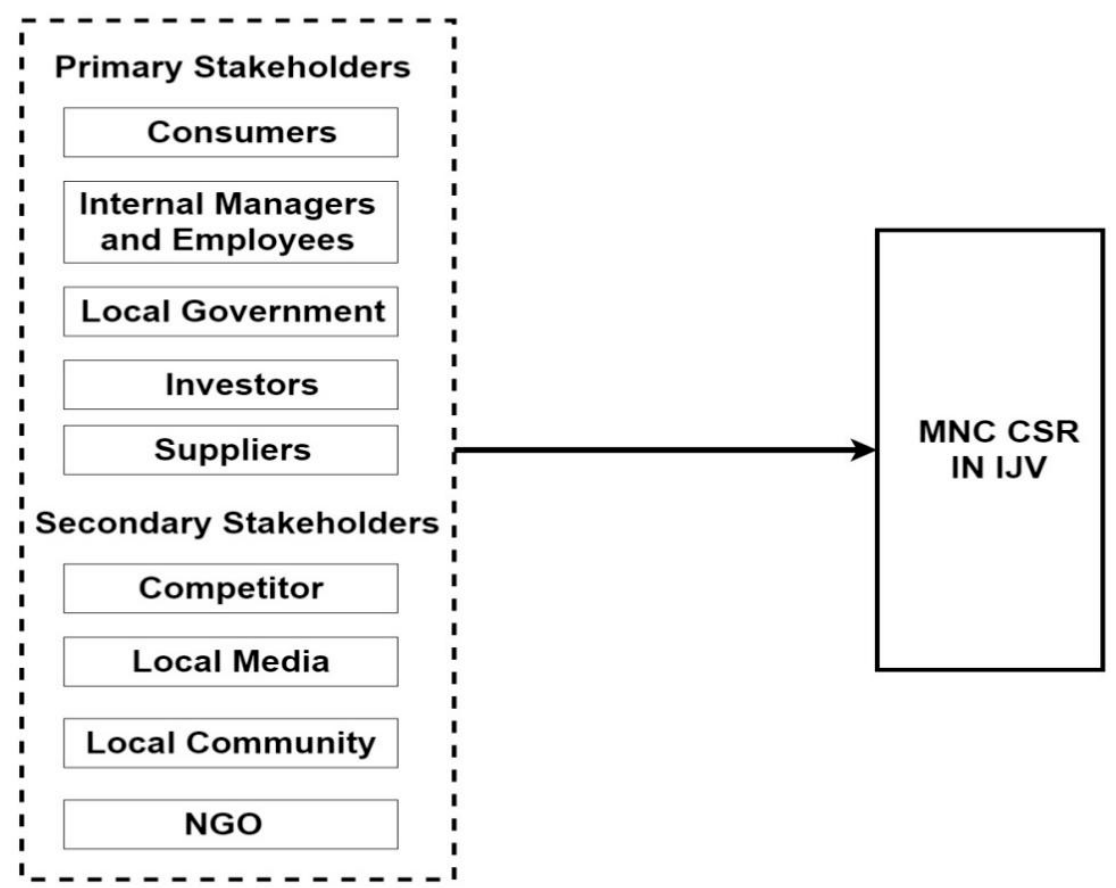

Figure 1. Conceptual framework.

\section{Research Methodology}

\subsection{Data Sample and Collection}

We conducted this study from October 2019 and collected data over four months. The research population comprises the subsidiaries of Ghana-based MNC [66]. The Ghana Investment Promotion Centre, an agency of the government, periodically issues reports detailing subsidiaries that are duly registered in Ghana, and it is responsible for monitoring all foreign investment operations in the country. Following the official government list we obtained, we proceeded to check the institutional website of these firms in order to confirm if their operations still exist or whether they were still in business with their local partners. Upon completing this exercise, we had a total of 1105 organizations (excluding those whose websites could not be found and those whose websites were not operational). Questionnaires were delivered by email to prospective respondents and subsequent followups were made. After completing the survey, we had 260 responses in all, with a response rate of $23.51 \%$. Out of this number, 15 of them were unusable for the purpose of our research, hence they were excluded. Therefore, the remainder of 245 responses was used for our analysis. Of the 245 companies, 124 belong to WOSs, and 121 belong to IJVs. 


\subsection{Variable Measurement}

In this study, IJV CSR is the dependent variable and was assessed with 12 items using the Likert-type responses. Nine independent variables, based on the stakeholder theory, were listed as factors likely to have an impact on the CSR levels and measured using a five-point Likert scale. The following part provides further details as to how the dependent variables were measured. Included in Appendix A are the independent variables (with the items used in measuring them), the origin of these variables, as well as Cronbach's alpha.

To control the impact of other factors associated with the CSR of IJVs, we employed five control variables for our research.

The economic status of a country may be a determining factor of how firms behave towards CSR, suggesting that multinational enterprises from advanced countries presumably know more about CSR as compared to those from developing nations [17,67]. Therefore, to control how foreign subsidiaries' behaviors are affected by economic development levels, we used a dummy variable sourced from Park and Ghauri [17] to represent the expectancy (" 1 " for IJVs whose foreign partner is from an advanced nation and " 2 " for those coming from a developing country).

Reasonably, the institutional regulations for legitimacy should differ from one country to another. We drew on the three domains of institutional environment proposed by the authors of Reference [25]: The regulatory, the normative, and the cognitive. They [25] also suggest that complexity can be seen with multinational corporations whose subsidiaries are not only fragmented by geographical regions but also separated by functions or tasks. Due to this, each subsidiary of the MNC faces its host institutional environment which differs from one country to another. Based on this finding, we measured the variable with three items using a 5-point Likert scale (i.e., we measured the perceived institutional distance between the host and home countries in terms of the regulatory, normative, and cognitive domains).

The ownership structure, as suggested by Li et al. [68], also affects organizational communication that relates to CSR practices. Multinational companies from developed countries may possess higher standards for CSR as compared to local partners, and for these MNCs who suffer foreignness in new markets to obtain legitimacy, they are more likely to pursue CSR. The ownership structure was ordinarily measured in prior research by evaluating the IJVs ownership proportions, similar to Mata and Portugal [69]. This measurement was employed for stage 1 of our study. For stage 2, we followed the measurements by Park and Cave [4] by dividing it into 3 categories based on the share of equity (i.e., local parent majority ownership, 50/50 shared ownership, and foreign parent majority ownership).

The size of the organization is assessed by considering how many employees it has. On the other hand, the age of the subsidiary is defined by how many years the subsidiary has been in existence after it was created. In prior studies, these two items have been generally used as controls while exploring the CSR of MNCs [12].

This research included a questionnaire which was adopted from Luo [70] and Park and Cave [4]. To ensure its fitness to the Ghanaian situation, the questionnaire was given to 30 managers for review. We received feedback from 18 of the 30 managers, and to the best of their knowledge, the questionnaire had extensive coverage of all relevant areas. The questionnaires were then administered to respondents who were the top managers of the IJVs to perceptually evaluate the dependent and independent variables. Moreover, this could potentially lead to the issue of common method variance. To deal with any possible barriers, we extensively reviewed existing literature in similar areas to find out any items that were validated by previous studies. Additionally, we had interviews with 8 respondents soon after completing our survey to assess the consistency in the responses. No major variations were identified when the findings and survey results were compared; thereby suggesting that common method variance is negligible in our study [70]. According to the authors of Reference [71], a considerable level of common method bias exists in two instances: either (i) a single factor emerges from the factor analysis or (ii) one general factor will account for the majority of the covariance among 
the measures. Therefore, we performed Harman's single-factor test to investigate the existence of common method variance in our study. The result showed a single factor with a total variance explained of $21.29 \%$. Therefore, based on the aforementioned results, we recommend ignoring the issue of common method bias in our study.

\section{Results}

\subsection{Results of the First Stage of Analysis}

This study is divided into two stages of analysis: the first stage seeks to examine how stakeholders impact the CSR practices of IJVs in local markets and the second stage focuses on the IJV structure in order to ascertain possible variations in CSR behavior. Before analyzing our data, we carefully observed the correlation among variables showed in Table 1 for any potential presence of multicollinearity. Many proposed cut-off points, with a range from 0.7 to 0.9 , have been put forth for defining multicollinearity [72,73]. Nonetheless, from the observations in Table 1, it is clear that there is no value that falls between the suggested ranges inferring that multicollinearity is negligible in this study. To further tackle any probable case of multicollinearity that may arise, an evaluation of the variance inflation was carried out. Hair et al. [74] propose that the highest value of VIF which is acceptable is 5.00. Observing the VIF values from Table 2, the highest value is 1.645 , hence multicollinearity is negligible. 
Table 1. Descriptive statistics and correlations.

\begin{tabular}{|c|c|c|c|c|c|c|c|c|c|c|c|c|c|c|c|c|c|}
\hline & & \multirow{2}{*}{ Mean } & \multirow{2}{*}{ S.D. } & \multicolumn{14}{|c|}{ Correlation } \\
\hline & & & & 1 & 2 & 3 & 4 & 5 & 6 & 7 & 8 & 9 & 10 & 11 & 12 & 13 & 14 \\
\hline 1. & $\begin{array}{l}\text { Development status of } \\
\text { MNC origin }\end{array}$ & 1.41 & 0.49 & 1 & & & & & & & & & & & & & \\
\hline 2. & Ownership structure & 1.93 & 0.48 & $-0.201 *$ & 1 & & & & & & & & & & & & \\
\hline 3. & Institutional distance & 2.58 & 0.72 & -0.064 & 0.012 & 1 & & & & & & & & & & & \\
\hline 5. & Subsidiary age & 2.82 & 0.88 & 0.021 & 0.11 & $-0.220 *$ & 0.176 & 1 & & & & & & & & & \\
\hline 6. & Consumers & 4.44 & 0.49 & 0.022 & -0.077 & -0.1 & 0.065 & 0.079 & 1 & & & & & & & & \\
\hline 7. & $\begin{array}{l}\text { Internal managers and } \\
\text { employees }\end{array}$ & 3.49 & 0.42 & $-0.279 * *$ & -0.057 & 0.138 & 0.09 & 0.062 & $0.258^{* *}$ & 1 & & & & & & & \\
\hline 8. & Government & 3.48 & 0.59 & 0.089 & -0.033 & $-0.235^{* *}$ & -0.098 & 0.011 & $0.215 *$ & 0.053 & 1 & & & & & & \\
\hline 10. & Investors & 3.84 & 1.0 & 0.084 & -0.121 & -0.154 & -0.036 & $0.192 *$ & 0.097 & 0.091 & $0.295 * *$ & 0.098 & 1 & & & & \\
\hline 11. & Competitors & 3.80 & 0.61 & $0.179 *$ & -0.083 & -0.144 & 0.075 & 0.11 & 0.107 & 0.161 & 0.068 & -0.048 & 0.072 & 1 & & & \\
\hline 12. & Media & 4.12 & 0.87 & 0.119 & $0.421 * *$ & 0.071 & -0.082 & 0.059 & -0.025 & -0.124 & -0.026 & 0.062 & 0 & $0.347^{* *}$ & 1 & & \\
\hline 13. & Local Community & 3.49 & 0.47 & -0.132 & 0.072 & -0.093 & -0.168 & 0.01 & -0.113 & -0.018 & -0.011 & 0.026 & 0.097 & 0.085 & 0.028 & 1 & \\
\hline 14. & NGO & 3.64 & 0.58 & 0.148 & -0.005 & -0.137 & 0.107 & -0.046 & 0.117 & 0.131 & 0.178 & 0.123 & 0.145 & 0.087 & -0.081 & 0.064 & 1 \\
\hline 15. & CSR & 3.66 & 0.43 & -0.029 & -0.138 & 0.028 & 0.049 & 0.042 & $0.276^{* *}$ & $0.309 * *$ & $0.320 * *$ & $0.199 *$ & $0.241 * *$ & $0.301 * *$ & 0.038 & $0.261 * *$ & 0.119 \\
\hline
\end{tabular}

Notes: S.D. $=$ standard deviation. Number $=121 ;{ }^{*} p<0.05 ;{ }^{* *} p<0.01$ 
Table 2. Analysis results: Ordinary Least Squares (OLS) regression (stepwise).

\begin{tabular}{|c|c|c|c|c|c|}
\hline & Model 1 & Model 2 & Model 3 & Model 4 & VIF \\
\hline $\begin{array}{l}\text { Development status of } \\
\text { MNC origin }\end{array}$ & $-0.103^{*}$ & -0.017 & $-0.158^{* *}$ & -0.061 & 1.422 \\
\hline Ownership structure & 0.062 & 0.140 & 0.083 & 0.078 & 1.142 \\
\hline Institutional distance & $-0.074 *$ & $-0.105^{*}$ & $-0.133 *$ & $-0.180 *$ & 1.536 \\
\hline Subsidiary size & 0.041 & 0.063 & 0.070 & 0.078 & 1.327 \\
\hline Subsidiary age & -0.106 & -0.044 & -0.075 & -0.019 & 1.391 \\
\hline Consumers & $0.276^{* * *}$ & & $0.317^{* * *}$ & $0.202 * * *$ & 1.598 \\
\hline $\begin{array}{l}\text { Internal managers and } \\
\text { employees }\end{array}$ & 0.156 * & & 0.118 & $0.195^{* *}$ & 1.916 \\
\hline Government & 0.061 & & 0.034 & 0.077 & 1.178 \\
\hline Suppliers & 0.012 & & 0.073 & 0.091 & 1.329 \\
\hline Investors & 0.071 & & 0.054 & 0.066 & 1.132 \\
\hline Competitors & & $0.246^{* * *}$ & $0.185^{* *}$ & 0.069 & 1.167 \\
\hline Media & & 0.027 & 0.048 & & 1.364 \\
\hline Local Community & & $0.249^{* * *}$ & $0.260 * * *$ & & 1.643 \\
\hline NGO & & 0.098 & 0.065 & & 1.094 \\
\hline $\begin{array}{l}\text { Internal managers and } \\
\text { employees } X\end{array}$ & & & & $-0.206^{* *}$ & \\
\hline Competitors & & & & & \\
\hline Adjusted $\mathrm{R}^{2}$ & 0.413 & 0.327 & 0.567 & 0.582 & \\
\hline $\mathrm{F}$ & $21.649 * * *$ & $18.526^{* * *}$ & $29.985^{* * *}$ & $35.694^{* * *}$ & \\
\hline
\end{tabular}

Notes: Coefficients standardized, ${ }^{*} p<0.05 ;{ }^{* *} p<0.01 ;{ }^{* *} p<0.001$.

The regression analysis results of stage 1 are shown in Table 2. The first Model consists of the control variables and the primary stakeholders expected to influence the IJV's CSR practices. Additionally, the second Model illustrates the control variables and the secondary stakeholders proposed to influence the CSR practices of IJVs. In the third Model, it combines the control variables with both the primary and secondary stakeholders. Results show that each model is significant at $p<0.001$, as can be seen from Table 2 .

As shown in Table 3, the first stage considers the IJV and expects a strong influence of each stakeholder on the IJV's CSR activities. The result of the regression analysis gives support to H1 (Consumers), H6 (Competitors), and H8 (Local community) as each displayed statistical significance. The results also suggest that, H3 (Governments), H4 (Suppliers), H5 (Investors), H7 (Media), and H9 (NGOs) were unsupported. H2 (Internal managers and employees) was partially supported.

\subsection{Results of the Second Stage of Analysis}

The second part of the study centers on the IJV's structure and seeks to find out if there are any statistically significant variations, testing H10 (Ownership structure) and H11 (IJV against WOS). As shown in Table 4, we found some significant variations in the level of CSR among the three IJVs ownership types. The IJV with foreign parent majority ownership recorded the highest level of CSR, with the local majority ownership recording the least. Hence, we find support to the hypothesis (H10). 
Table 3. The results of the empirical analyses.

Hypotheses Results

H1: Consumers are a relevant stakeholder group that have positive impacts on how IJVs pursue CSR activities in a foreign market.

Support

H2: IJV managers and employees are a relevant stakeholder group that have positive impacts on how IJVs pursue CSR activities in a foreign market.

Partially Support

H3: Government is a relevant stakeholder group that have positive impacts on how IJVs pursue CSR activities in a foreign market.

Reject

H4: Suppliers are a relevant stakeholder group that have positive impacts on how IJVs pursue CSR activities in a foreign market.

H5: Investors are a relevant stakeholder group that have positive impacts on how IJVs pursue CSR activities in a foreign market.

Reject

H6: Competitors are a relevant stakeholder group that have positive impacts on how IJVs pursue CSR activities in a foreign market.

H7: The Media is a relevant stakeholder group that has positive impacts on how IJVs pursue CSR activities in a foreign market.

H8: The local community is a relevant stakeholder group that has positive impacts on how IJVs pursue CSR activities in a foreign market.

H9: NGOs are a relevant stakeholder group that have positive impacts on how IJVs pursue CSR activities in a foreign market.

H10: The foreign parent majority ownership type will demonstrate greater levels of CSR in comparison to the 50/50 ownership type, sequentially demonstrating greater CSR levels than the local parent majority ownership type.

H11: Wholly Owned Subsidiaries will demonstrate higher levels of CSR as compare to IJVs. 
Table 4. Analysis of variance (ANOVA) of CSR by ownership.

\begin{tabular}{cccccc}
\hline & Number & Mean & S.D. & F-Ratio & $\begin{array}{c}\text { Significance } \\
\text { Level (Sig.) }\end{array}$ \\
\hline $\begin{array}{c}\text { Foreign parent } \\
\text { majority ownership }\end{array}$ & 103 & 3.731 & 0.390 & 14.719 & 0.000 \\
$\begin{array}{c}\text { Equal ownership split } \\
\text { Local parent majority } \\
\text { ownership }\end{array}$ & 10 & 3.375 & 0.480 & & \\
\hline
\end{tabular}

Testing for H11 (IJV vs WOS) involved comparing IJVs against WOSs using the twelve items employed to evaluate CSR behavior, which is shown in Table 5. From the table, we observed that on all twelve response items, IJVs record a lower mean, finding support for hypothesis 11 .

Table 5. T-Test: IJV vs. wholly owned subsidiaries (WOSs).

\begin{tabular}{|c|c|c|c|c|}
\hline & & IJVs $(N=121)$ & WOSs $(\mathrm{N}=124)$ & $\begin{array}{l}\text { Significance } \\
\text { Level } \\
\text { (Cronbach's } \\
\text { Alpha: 0.920) }\end{array}$ \\
\hline $\begin{array}{l}\text { CSR } \\
1:\end{array}$ & $\begin{array}{l}\text { Our company has established a set } \\
\text { of transparent, comprehensive, } \\
\text { and stringent codes of conduct } \\
\text { aiming at resisting bribery, } \\
\text { corruption, and other illicit acts in } \\
\text { the host country. }\end{array}$ & 3.81 & 3.97 & 0.007 \\
\hline $\begin{array}{l}\text { CSR } \\
2:\end{array}$ & $\begin{array}{l}\text { Throughout the company, every } \\
\text { manager and employee has strictly } \\
\text { implemented the above codes of } \\
\text { conduct. }\end{array}$ & 3.75 & 3.87 & 0.075 \\
\hline $\begin{array}{l}\text { CSR } \\
\text { 3: }\end{array}$ & $\begin{array}{l}\text { Our company has established an } \\
\text { ethics compliance department or } \\
\text { division that specifically handles } \\
\text { the improvement, training, and } \\
\text { enforcement of the above codes of } \\
\text { conduct. }\end{array}$ & 3.52 & 3.72 & 0.003 \\
\hline $\begin{array}{l}\text { CSR } \\
4:\end{array}$ & $\begin{array}{l}\text { Our company always attaches the } \\
\text { utmost value to, and takes actual } \\
\text { steps in, enhancing corporate } \\
\text { image and reputation. }\end{array}$ & 3.65 & 3.88 & 0.000 \\
\hline $\begin{array}{l}\text { CSR } \\
5:\end{array}$ & $\begin{array}{l}\text { Our company always honors our } \\
\text { promises regarding product } \\
\text { and/or service offerings and is } \\
\text { dedicated to adapting to the local } \\
\text { consumers' needs. }\end{array}$ & 3.73 & 3.91 & 0.000 \\
\hline
\end{tabular}


Table 5. T-Test: IJV vs. wholly owned subsidiaries (WOSs).

\begin{tabular}{|c|c|c|c|c|}
\hline & & IJVs $(N=121)$ & WOSs $(\mathrm{N}=124)$ & $\begin{array}{c}\begin{array}{c}\text { Significance } \\
\text { Level } \\
\text { (Cronbach's } \\
\text { Alpha: } 0.920 \text { ) }\end{array}\end{array}$ \\
\hline $\begin{array}{l}\text { CSR } \\
6:\end{array}$ & $\begin{array}{l}\text { Relying on its honesty and } \\
\text { credibility, our company has } \\
\text { maintained good and stable } \\
\text { relationships with local suppliers, } \\
\text { distributors, and other business } \\
\text { partners. }\end{array}$ & 3.91 & 4.10 & 0.000 \\
\hline $\begin{array}{l}\text { CSR } \\
7:\end{array}$ & $\begin{array}{l}\text { Each year, our company allocates } \\
\text { some portion of retained earnings } \\
\text { to charitable organizations. }\end{array}$ & 3.52 & 3.78 & 0.000 \\
\hline $\begin{array}{l}\text { CSR } \\
8:\end{array}$ & $\begin{array}{l}\text { Our company always recognizes } \\
\text { its social responsibility and } \\
\text { participates in helping the needy } \\
\text { and the outcasts of society and } \\
\text { improving a backward facility of } \\
\text { the local community. }\end{array}$ & 3.71 & 3.81 & 0.051 \\
\hline $\begin{array}{l}\text { CSR } \\
9:\end{array}$ & $\begin{array}{l}\text { Each year, our company uses some } \\
\text { portion of retained earnings to } \\
\text { help the local community to } \\
\text { consummate the public } \\
\text { infrastructure and environmental } \\
\text { protection. }\end{array}$ & 3.47 & 3.66 & 0.008 \\
\hline $\begin{array}{l}\text { CSR } \\
10:\end{array}$ & $\begin{array}{l}\text { The resources (e.g., technology, } \\
\text { skills, capital, or equipment) we } \\
\text { invested in local project(s) are } \\
\text { always complementary to the host } \\
\text { country's economic development } \\
\text { needs. }\end{array}$ & 3.62 & 3.79 & 0.001 \\
\hline $\begin{array}{l}\text { CSR } \\
11:\end{array}$ & $\begin{array}{l}\text { We always invest resources (e.g., } \\
\text { technology, skills, capital, or } \\
\text { equipment) that the local } \\
\text { government needs for social } \\
\text { development. }\end{array}$ & 3.60 & 3.81 & 0.000 \\
\hline $\begin{array}{l}\text { CSR } \\
12:\end{array}$ & $\begin{array}{l}\text { The resources (e.g., technology, } \\
\text { skills, capital, or equipment) we } \\
\text { invested in local project(s) always } \\
\text { contribute to industrial } \\
\text { development by enhancing } \\
\text { technological and managerial } \\
\text { knowledge in the local market. }\end{array}$ & 3.57 & 3.88 & 0.000 \\
\hline
\end{tabular}

Notes: Dependent variable measurements were adopted from Luo [70]. N=Number.

\section{Discussion}

This research provides a detailed examination of how various stakeholders and the ownership structure impact the level of CSR in IJVs. Consumers are certainly key stakehold- 
ers that influence CSR behavior, comparable to prior CSR research [31]. When consumers reckon that a firm is acting in an undesirable manner, particularly when they have easy access to readily available and unrestricted information, they tend to exert pressure on that firm. They also react similarly when they have access to a large number of alternative sources to choose from. Firms can increase the loyalty of consumers, resulting in consumers becoming ambassadors of the company when firms position themselves as responsible members of society [75]. This study confirms that the role of consumers is principal regarding a company's direction and its choice to actively undertake CSR activities in the local market.

Internal managers and employees were also predicted as influential stakeholders and this hypothesis was partially supported, as per our results. The role of internal managers and employees is significant in Model 1, but insignificant in Model 3. In Model 4, we conducted further tests to find the reason for the insignificance of their role and we find that this occurred due to competitors' pressure. Although an IJV is essentially two or more companies, there might be the instance where employees may lack the desire to implement ethical and responsible behavior. However, they might respond to corporate social responsibility in the face of pressure from fierce competition. This may be due to the fact that in an IJV, employees associate themselves with their parent organization rather than the IJV itself, and act mainly in the competitive environment [4].

The next stakeholder our studies found to be influential on IJV CSR was competitors as it displayed statistical significance. A firm would not want to give its competitors any advantage over itself and therefore, if a competitor practices CSR, the firm (including IJVs) would respond in a like manner. This act of emulation propels the growth of CSR, making sure that the CSR practices of a firm cannot emerge as a distinguishing factor in the local market, according to Laudal [50]. Likewise, Bondy et al. [51] advance that MNCs are likely to recognize their current CSR definitions as well as practices and to analyze competitor behavior in order to retain market share by tracking the CSR strategies of the competitor.

Another influential stakeholder on the CSR of IJVs was local community, as we found support for its prediction in our studies. In Ghana, local communities put pressure on organizations, which operate within the community, to act ethically and responsibly as well as to pay attention to the needs of the community. This is consistent with studies carried out by Amponsah-Tawiah and Dartey-Baah [76], which suggested that CSR in some industries (for example in the mining industry) began as a reactive measure to the complaints and demands of community members and have now evolved into a proactive strategy of engagement. This infers that firms, including IJVs, now design strategies that incorporate the concerns of the local community where they operate, being suggestive of an influence of the local community on the firm's behavior and decisions.

The Government's role in predicting IJVs' CSR activities was not supported in our studies. It remained insignificant in all models, which is suggestive of the government's choice to stimulate FDI by creating open doors for MNCs, without loading IJVs with too much pressure regarding CSR. This is consistent with the findings by Park and Cave [4] that put forward the argument that though regulations exist and are generally observed, there seems to be less sternness regarding the conditions of establishment and the collaboration between the foreign and local firms to participate in CSR. They also state that while governments in developing countries may require lower levels of CSR, MNCs may decide to pursue some level of CSR activities, thereby annulling the obligation of governments' need to interfere and enforce mandatory ethical actions. Although there are some laws regarding CSR in Ghana, these laws are not enforced by regulatory agencies, thereby leading to CSR mostly being a voluntary action [77].

Suppliers remained insignificant in both models, hence unsupported in our studies. Some research [4] suggests a negative relationship between CSR and suppliers. However, our findings suggest that suppliers have insignificant influence on the CSR activities of IJVs. According to studies carried out by Williams et al. [78], the majority of MNCs in Ghana established working relationships with local suppliers primarily to have easy 
access to inputs and local production techniques. An additional reason was in order to build the capacity of firms as well as to create market opportunities for actors along the production chain within the firms. In Ghana, it seems that most suppliers generally do not pay attention to the CSR activities of joint ventures, nor are they inclined to put pressure on organizations dealing with them to take responsible or ethical actions. The suppliers tend to focus ultimately on maximizing sales and yielding maximum profits $[79,80]$. Furthermore, with the growing competitiveness among suppliers in the Ghanaian market, business survival and continuity are of paramount interest as opposed to monitoring and influencing the activities of IJVs.

Investors were also unsupported in our study as it showed insignificance in all models. This result infers that investors in IJVs are not so much interested in how ethical the IJV is or whether it engages in CSR, but instead they are more focused on prospective earnings and the potential to generate profit. Most of the developed countries are where philanthropic culture is valued [17], which might not be the case in Ghana. Similar to the ideology of investors in some developing countries, Ghanaian investors are generally more inclined to creating wealth for their children and families only and seldom participate in philanthropy. This may well be a direct result of the local environment where ethical and social needs, as well as philanthropy, are viewed as trivial to investors as compared to the creation of wealth (considering the limited lifespan of IJVs).

According to the results of our study, media as a stakeholder displayed a lack of significance, inferring that it is not influential on the CSR activities of IJVs. The media is often perceived as extremely important when it comes to negative reviews and its ability to control consumers' perception about a firm or its products and services. The insignificance of media in our study possibly derives its reasoning from the structure of the IJV itself. According to O'Riordan and Fairbrass [52], they point out that because the local media is generally interested in large MNCs and corporate powerhouses, it is less likely to establish big cases against IJVs which are mostly smaller in size. Our research further identified that the influence of media is not significant. This is because Ghana's joint ventures are inherently small and therefore can avoid media attention or censorship. Another reason may be that the media is not professional and powerful enough, so its impact on IJVs is limited.

Finally, to our surprise, we found that NGOs are an uninfluential stakeholder in predicting an IJV's CSR activities. This contradicts existing research [81] which suggests that NGOs serve as civil society representatives who promote MNCs to meet societal expectations for beneficial strategies which will impact their transaction costs and foreign operational efficiency. It is imperative to note the importance of NGOs in social development. The insignificance of NGOs in our study could be that NGOs in Ghana are generally undeveloped and too small; or, it could be that they mostly liaise with companies for funds to engage in their activities. Thus, in the main, they do not actively exert pressure on firms, including IJVs, to be socially responsible but rather act as a form of conduit for firms to fulfill their expectations from society.

The second phase of our research examined how CSR activities relate to the structure of the IJV. In this paper, IJVs are categorized into three types: local parent majority ownership, equally shared ownership, and foreign parent majority ownership. Our results, as highlighted in Table 4, are in line with our expectations that IJVs with foreign majority ownership will pursue the highest level of CSR, followed by those with equally shared ownership, and the local parent majority ownership recording the least. Hence, H10 was supported in our study. Because of the level of advancement and the higher level of standards required in the home markets where the foreign parent comes from, the foreign parent is more accustomed to the practice of CSR, and hence its active pursuit of CSR in the host market. Also, we see IJVs with local dominant ownership engage in CSR at a much lower degree. From our data, we realized that the size of IJVs with local majority ownership was relatively smaller compared to IJVs with foreign majority ownership. This could mean 
a strain on the company's profits and therefore potentially limit its ability to actively engage in CSR.

The second phase of this study also compared IJVs to WOSs in terms of CSR practices. We expected WOSs, as compared to IJVs, to pursue higher levels of CSR in the local market. From Table 5, we find support for this hypothesis as we found significant differences in all but two items of the CSR scale. That is to say that there were differences between IJVs and WOSs in 10 items. The first half of the items used in measuring CSR are generally connected with code of conduct, whist the second half is linked to contributions made in the short-term and philanthropic efforts or important long-term community development investments. Research by Amponsah-Tawiah and Dartey-Baah [76] indicates that MNCs pioneered CSR initiatives in Ghana have been instrumental in the country's social development. This means that not only do MNCs serve as a vehicle for the creation of an ethical atmosphere, but they also actively pursue CSR activities as in the case of Ghana.

\section{Conclusions}

As one of the fastest-growing economies in Africa, Ghana actively promotes the investment activities of MNCs in the country and is undergoing a process of ethical management and CSR transformation. Existing MNC-based CSR research focuses on large developing countries and ignores African countries such as Ghana; in addition, existing research lacks attention to the CSR practices of IJVs. Since the institutional environment in Ghana is different from that of developed countries, at the same time, an IJV has a unique organizational structure different from a WOS of a MNC, which makes the CSR practices of IJVs in emerging developing countries such as Ghana important and worthy of study.

Initially, our study began by assessing how impactful stakeholders are on the CSR practices of IJVs in a developing market. Then, it continued to find possible structural differences in the IJV and the effects of ownership on its adoption of CSR strategies. Finally, we compared IJVs to WOSs in terms of CSR. We found that IJVs are influenced by significantly positive pressures exerted by consumers, competitors, and the local community. We see that from a Ghanaian viewpoint, in that not every stakeholder has a significant influence on the activities of the joint venture. In Ghana, the influence of the government, suppliers, investors, media, and NGOs on the CSR activities of joint ventures is not significant. We examined the reasons for these results in the discussion section. The structure analysis result revealed that IJVs with foreign majority ownership pursue CSR at the highest rate, followed by the equal ownership, and the local majority ownership having the least rate. Comparing IJVs against WOSs, WOSs pursued CSR at a higher rate.

Our study makes further contributions to stakeholder theory by revealing the main elements stimulating CSR activities in IJVs. Stakeholders in a given business environment can apply enormous pressure on the CSR activities of a firm by exercising direct control over an organization's resource allocation. Stakeholders' influence could be a significant institutional setting which IJVs operate in. Therefore, what stimulates an IJV to adopt CSR practices can be linked to the requirements and concern of all local stakeholders involved. To this end, it has important research value to understand the impact of stakeholders on the CSR activities of IJV in a specific region (such as Ghana), identify which stakeholders have a significant influence and which stakeholders have no significant influence, and analyze the reasons leading to these results. Along these lines of thinking, our research has provided support for the host country to promote the development of IJV-related stakeholders. In addition, our research has contributed to the literature related to joint ventures. Currently, IJVs have become a strategy to curb the basic problems faced by MNCs (such as foreign responsibilities and insufficient market knowledge). Our study establishes a potential framework for any MNCs exploring new markets and looking to set up an IJV. This research can help multinational companies determine the appropriate organizational structure for joint ventures and improve their relationships with stakeholders by implementing CSR strategies. 
This study is not without some limitations. First and foremost, our research was carried out in a single geographical location, hence a possible limitation to how universally applicable the results can be. Pressure from stakeholders and environmental issues resulting in decreasing or intensifying pressure on CSR may differ compared to other countries and the potential difference could be considerable. Additionally, this study does not differentiate between subsidiary age and size, which may play roles in determining the firm's orientation toward CSR. The subsidiary's age and size variations may be linked to the energy levels channeled into the pursuit of CSR as they pursue market expansion or may entail other facets like codes of ethics. Equally, this research did not consider industry variations while examining IJVs, which could reveal a greater understanding of how stakeholders influence IJVs' CSR activities in different industries.

Author Contributions: Conceptualization, G.T. and G.D.P.; methodology, G.D.P.; software, H.C.; validation, H.S., G.T. and G.D.P.; formal analysis, G.T. and G.D.P.; investigation, H.C.; resources, H.S.; data curation, G.D.P.; writing-original draft preparation, G.T. and G.D.P.; writing-review and editing, X.W.; visualization, G.T.; supervision, X.W.; project administration, G.T. and H.S. All authors have read and agreed to the published version of the manuscript.

Funding: This research was funded by the National Philosophy and Social Sciences Foundation of China (20BGL113), the National Natural Science Foundation of China (Grant No. 71774071), and the Key Project of Jiangsu Social Science Fund, China (Grant No. 20ZLA007).

Conflicts of Interest: The authors declare no conflict of interest.

\section{Appendix A}

Table A1. Independent variable measurements.

\begin{tabular}{|c|c|c|}
\hline Variable & $\begin{array}{c}\text { Measurement (Ranging from } 1=\text { Very Strongly Disagree to } 5=\text { Very Strongly } \\
\text { Agree) }\end{array}$ & Cronbach's Alpha \\
\hline $\begin{array}{l}\text { Consumers (Adapted from Tian, Wang, } \\
\text { and Yang [82]) }\end{array}$ & $\begin{array}{l}\text { (I) Consumers care about environmental protection in the daily consumption. } \\
\text { (II) Consumers pay attention to some social issues involving firm's charitable } \\
\text { donations. (III) Consumers tend to buy those products which are produced by } \\
\text { firms that are socially responsible rather than goods which are fine and } \\
\text { inexpensive. }\end{array}$ & 0.879 \\
\hline $\begin{array}{l}\text { IJV managers and employees (Adapted } \\
\text { from Munilla and Miles [83]) }\end{array}$ & $\begin{array}{l}\text { (I) Our managers and employees perceive CSR as an important mechanism } \\
\text { potentially contributing to the creation of corporate value. (II) Our managers } \\
\text { and employees perceive that CSR enhances competitive advantage, and } \\
\text { eventually improves the economic value of the firm. (III) Our managers and } \\
\text { employees believe firms need to contribute to local countries, societies, and } \\
\text { markets. (IV) Our managers and employees believe being ethical and socially } \\
\text { responsible is the most important thing a firm should do. }\end{array}$ & 0.824 \\
\hline Governments (Adapted from Qu [84]) & $\begin{array}{l}\text { (I) The local government has stricter regulations to protect the consumers. (II) } \\
\text { The local government has effective regulations to encourage firms to improve } \\
\text { their product and services quality. (III) There are complete laws and regulations } \\
\text { to ensure fair competition. }\end{array}$ & 0.933 \\
\hline $\begin{array}{l}\text { Suppliers (Adopted from Park and Cave } \\
\qquad[4] \text { ) }\end{array}$ & $\begin{array}{l}\text { (I) Local suppliers tend to prefer close cooperation with firms which are socially } \\
\text { responsible. (II) Local suppliers tend to prefer the maintenance of cooperation } \\
\text { with firms which are socially responsible. (III) Local suppliers have a propensity } \\
\text { to apply social and environmental requirements to their business relationships. }\end{array}$ & $0.98 \mathrm{I}$ \\
\hline Investors (Adopted from Park et al. [59]) & $\begin{array}{l}\text { (I) Investors tend to prefer investment into firms which are socially responsible. } \\
\text { (II) Investors expect firms to implement various and active CSR practices in host } \\
\text { country. (III) Investors actively indicate and support firms' CSR practices. }\end{array}$ & 0.985 \\
\hline $\begin{array}{l}\text { Competitors (Adapted from Lindgreen } \\
\text { et al. [33]) }\end{array}$ & $\begin{array}{l}\text { Due to local business environment, firms suffer from pressure on emulating } \\
\text { competitors' (I) social, (II) environmental, and (III) ethical policies and practices. }\end{array}$ & 0.925 \\
\hline $\begin{array}{l}\text { Media (Adopted from Park and Cave } \\
\text { [4]) }\end{array}$ & $\begin{array}{l}\text { (I) Media plays a pivotal role in maintaining and improving public relations } \\
\text { between firms and consumers in the local market. (II) Mass media has a strong } \\
\text { power in shaping corporate image and reputation in the local market. (III) } \\
\text { Compared with other countries, mass media in Korea pays more attention to the } \\
\text { societal role of firms in the local market. }\end{array}$ & 0.939 \\
\hline $\begin{array}{l}\text { Local community (Adopted from Park } \\
\text { and Cave [4]) }\end{array}$ & $\begin{array}{l}\text { Local communities expect companies to contribute to society development by (I) } \\
\text { volunteering time and effort to local activities. (II) Getting involved in } \\
\text { community events in nonfinancial ways. (III) Providing jobs and treating their } \\
\text { employees well. }\end{array}$ & 0.850 \\
\hline NGOs (Adopted from Park et al. [59]) & $\begin{array}{l}\text { (I) NGOs police and supervise effectively corporate activities in the local market. } \\
\text { (II) NGOs have a propensity to attempt to influence the CSR activities of } \\
\text { corporate management by using various instruments. (III) NGO community in } \\
\text { the local market has a sufficient power to exert pressure on multinational } \\
\text { enterprises to change their behavior and corporate strategy on CSR activities. }\end{array}$ & 0.903 \\
\hline
\end{tabular}




\section{References}

1. Park, B.-I.; Giroud, A.; Mirza, H.; Whitelock, J. Knowledge acquisition and performance: The role of foreign parents in Korean IJVs. Asian Bus. Manag. 2008, 7, 11-32. [CrossRef]

2. Huang, M.-C.; Hsiung, H.-H.; Lu, T.-C. Re-examining the relationship between control mechanisms and international joint venture performance: The mediating roles of perceived value gap and information asymmetry. Asia Pac. Manag. Rev. 2015, 20, 32-43.

3. Chang, J.; Bai, X.; Li, J.-J. The influence of institutional forces on international joint ventures 'foreign parents' opportunism and relationship extendedness. J. Int. Market. 2015, 23, 73-93. [CrossRef]

4. Park, B.-I.; Cave, A.-H. Corporate social responsibility in international joint ventures: Empirical examinations in South Korea. Int. Bus. Rev. 2018, 27, 1213-1228. [CrossRef]

5. Egri, C.-P.; Ralston, D.-A. Corporate responsibility: A review of international management research from 1998 to 2007. J. Int. Manag. 2008, 14, 319-339. [CrossRef]

6. Ambec, S.; Cohen, M.-A.; Elgie, S.; Lanoie, P. The Porter hypothesis at 20: Can environmental regulation enhance innovation and competitiveness? Rev. Environ. Econ. Policy 2013, 7, 2-22. [CrossRef]

7. Lockett, A.; Moon, J.; Visser, W. Corporate social responsibility in management research: Focus, nature, salience and sources of influence. J. Manag. Stud. 2006, 43, 136-155. [CrossRef]

8. Galbreath, J. Building corporate social responsibility into strategy. Eur. Bus. Rev. 2009, 21, 109-127. [CrossRef]

9. Yin, J.; Jamali, D. Strategic Corporate Social Responsibility of Multinational Companies Subsidiaries in Emerging Markets: Evidence from China. Long Range Plan. 2016, 49, 541-558. [CrossRef]

10. Bartels, L.-F.; Johnson, P.-J.; Ahmed, U.-Z. International Equity Joint Ventures in Ghana and Cote d'Ivoire. J. Afr. Bus. 2002, 3, 5-30. [CrossRef]

11. Boateng, A. Determinants of capital structure. Int. J. Soc. Econ. 2004, 31, 56-66. [CrossRef]

12. Rathert, N. Strategies of legitimation: MNEs and the adoption of CSR in response to host-country institutions. J. Int. Bus. Stud. 2016, 47, 858-879. [CrossRef]

13. Yang, X.; Rivers, C. Antecedents of CSR practices in MNCs' subsidiaries: A stakeholder and institutional perspective. J. Bus. Ethic 2009, 86, 155-169. [CrossRef]

14. Freeman, R.-E. Strategic Management: A Stakeholder Approach; Pitman Publishing Inc.: Boston, MA, USA, 1984.

15. Kakabadse, N.-K.; Rozuel, C.; Lee-Davis, L. Corporate social responsibility and stakeholder approach: A conceptual review. Int. J. Bus. Gov. Ethic 2005, 1, 277-302. [CrossRef]

16. Maon, F.; Lindgreen, A.; Swaen, V. Designing and implementing corporate social responsibility: An integrative framework grounded in theory and practice. J. Bus. Ethic 2009, 87, 71-89. [CrossRef]

17. Park, B.-I.; Ghauri, P.-N. Determinants influencing CSR practices in small and medium sized MNE subsidiaries: A stakeholder perspective. J. World Bus. 2015, 50, 192-204. [CrossRef]

18. Post, J.-E.; Preston, L.-E.; Sachs, S. Managing the extended enterprise: The new stakeholder view. Calif. Manag. Rev. 2002, 45, 6-28. [CrossRef]

19. Sarkis, J.; Pilar, G.; Belarmino, A. Stakeholder pressure and the adoption of environmental practices: The mediating effect of training. J. Operat. Manag. 2010, 28, 163-176. [CrossRef]

20. Hadjikhani, A.; Lee, J.-W.; Ghauri, P.N. Network of MNC's socio-political behavior. J. Bus. Res. 2008, 61, 912-924. [CrossRef]

21. Scott, W.-R. Institutions and Organizations; Sage: Thousand Oaks, CA, USA, 2001.

22. Husted, B.-W.; Montiel, I.; Christmann, P. Effects of local legitimacy on certification decisions to global and national CSR standards by multinational subsidiaries and domestic firms. J. Int. Bus. Stud. 2016, 47, 382-397. [CrossRef]

23. DiMaggio, P.-J.; Powell, W.-W. The iron cage revisited: Institutional isomorphism and collective rationality in organizational fields. Am. Sociol. Rev. 1983, 48, 147-160. [CrossRef]

24. Campbell, J.-T.; Eden, L.; Miller, S.-R. Multinationals and CSR: Does distance matter? J. Int. Bus. Stud. 2012, 43, 84-106. [CrossRef]

25. Kostova, T.; Zaheer, S. Organizational legitimacy under conditions of complexity: The case of the multinational enterprise. Acad. Manag. Rev. 1999, 24, 64-81. [CrossRef]

26. Gifford, B.; Kestler, A.; Anand, S. Building local legitimacy into corporate social responsibility: Gold mining firms in developing nations. J. World Bus. 2010, 45, 304-311. [CrossRef]

27. Husted, B.; Allen, D.-B. Corporate social responsibility in the multinational enterprise: Strategic and institutional approaches. J. Int. Bus. Stud. 2006, 37, 838-849. [CrossRef]

28. Reimann, F.; Ehrgott, M.; Kaufmann, L.; Carter, C.-R. Local stakeholders and local legitimacy: MNEs' social strategies in emerging economies. J. Int. Manag. 2012, 18, 1-17. [CrossRef]

29. Tate, W.-L.; Ellram, L.M.; Kirchoff, J.-F. Corporate social responsibility reports: A thematic analysis related to supply chain management. J. Supply Chain Manag. 2010, 46, 19-44. [CrossRef]

30. Udayasankar, K. Corporate social responsibility and firm size. J. Bus. Ethic 2008, 83, 167-175. [CrossRef]

31. Mishra, S.; Suar, D. Does corporate social responsibility influence firm performance of Indian companies? J. Bus. Ethic 2010, 95, 571-601. [CrossRef]

32. Singh, J.; Sanchez, S.-M.; Bosque, I.-R. Understanding corporate social responsibility and product perceptions in consumer markets: A cross-cultural evaluation. J. Bus. Ethic 2007, 80, 597-611. [CrossRef] 
33. Lindgreen, A.; Swan, V.; Johnson, W.-J. Corporate social responsibility: An empirical investigation of U.S. organizations. J. Bus. Ethic 2009, 85, 303-323. [CrossRef]

34. Laczniak, G.-R.; Murphy, P.-E. Stakeholder theory and marketing: Moving from a firm-centric to a societal perspective. J. Pub. Policy Market. 2012, 31, 284-292. [CrossRef]

35. Hartman, L.-P.; Rubin, R.S.; Dhanda, K.K. The communication of corporate social responsibility: United States and European Union multinational corporations. J. Bus. Ethic 2007, 74, 373-389. [CrossRef]

36. Uçkun, S.; Arslan, A.; Yener, S. Could CSR Practices Increase Employee Affective Commitment via Moral Attentiveness? Sustainability 2020, 12, 8207. [CrossRef]

37. Guo, Z.; Hou, S.; Li, Q. Corporate Social Responsibility and Firm Value: The Moderating Effects of Financial Flexibility and R\&D Investment. Sustainability 2020, 12,8452.

38. Li, Y.-B.; Zhang, G.-Q.; Wu, T.-J.; Peng, C.-L. Employee's Corporate Social Responsibility Perception and Sustained Innovative Behavior: Based on the Psychological Identity of Employees. Sustainability 2020, 12, 8604. [CrossRef]

39. Greening, D.-W.; Gray, B. Testing a model of organizational response to social and political issues. Acad. Manag. J. 1994, 37, 467-498.

40. Erdogan, A.-M. Foreign direct investment and environmental regulations: A survey. J. Econ. Surv. 2014, 28, 943-955. [CrossRef]

41. Detomasi, D.-A. The political roots of corporate social responsibility. J. Bus. Ethic 2008, 82, 807-819. [CrossRef]

42. Cave, A.-H. Environmentally responsible management in international business: A literature review. Multinatl. Bus. Rev. 2014, 22, 78-102. [CrossRef]

43. Cheng, W.-L.; Ahmad, J. Incorporating stakeholder approach in corporate social responsibility (CSR): A case study at multinational corporations (MNCs) in Penang. Soc. Responsib. J. 2010, 6, 596-610. [CrossRef]

44. Faisal, M.-N. Sustainable supply chains: A study of interaction among the enablers. Bus. Proc. Manag. J. 2010, 16, 508-529. [CrossRef]

45. Lihong, Z.; Goffin, K. Managing the transition—supplier management in international joint ventures in China. Int. J. Physic. Distri. Logist. 2001, 31, 74-95. [CrossRef]

46. Zhang, M.; Ma, L.; Su, J.; Zhang, W. Do suppliers applaud corporate social performance? J. Bus. Ethic 2014, $121,543-557$. [CrossRef]

47. Angel, J.; Rivoli, P. Does ethical investing impose a cost upon the firm? A theoretical perspective. J. Investig. 1997, 6, 57-61. [CrossRef]

48. Adam, A.-M.; Shavit, T. How can a ratings-based method for assessing corporate social responsibility (CSR) provide an incentive to firms excluded from socially responsible investment indices to invest in CSR? J. Bus. Ethic 2008, 82, 899-905. [CrossRef]

49. O'Shaughnessy, K.-C.; Gedajlovic, E.; Reinmoeller, P. The influence of firm, industry and network on the corporate social performance of Japanese firms. Asia Pac. J. Manag. 2007, 24, 283-303. [CrossRef]

50. Laudal, T. Drivers and barriers of CSR and the size and internationalization of firms. Soc. Responsib. J. 2011, 7, 234-256. [CrossRef]

51. Bondy, K.; Moon, J.; Matten, D. An institution of corporate social responsibility (CSR) in multi-national corporations (MNCs): Form and implications. J. Bus. Ethic 2012, 111, 281-299. [CrossRef]

52. O'Riordan, L.; Fairbrass, J. Corporate social responsibility (CSR): Models and theories in stakeholder dialogue. J. Bus. Ethic 2008, 83, 745-758. [CrossRef]

53. Demirbag, M.; Mirza, H. Factors affecting international joint venture success: An empirical analysis of foreign-local partner relationships and performance in joint ventures in Turkey. Int. Bus. Rev. 2000, 9, 1-35. [CrossRef]

54. Azmat, F; Samaratunge, R. Responsible entrepreneurship in developing countries: Understanding the realities and complexities. J. Bus. Ethic 2009, 90, 437-452. [CrossRef]

55. Gugler, P.; Shi, J.Y.-J. Corporate social responsibility for developing country multinational corporations: Lost war in pertaining global competitiveness? J. Bus. Ethic 2009, 87, 3-24. [CrossRef]

56. Beamish, P.-W.; Lupton, N. Managing joint ventures. Acad. Manag. Perspect. 2009, 23, 75-94. [CrossRef]

57. Russo, A.; Perrini, F. Investigating stakeholder theory and social capital: CSR in large firms and SMEs. J. Bus. Ethic 2010, 91, 207-221. [CrossRef]

58. Sen, S.; Cowley, J. The relevance of stakeholder theory and social capital theory in the context of CSR in SMEs: An Australian perspective. J. Bus. Ethic 2013, 118, 413-427. [CrossRef]

59. Park, B.-I.; Chidlow, A.; Choi, J. Corporate social responsibility: Stakeholders influence on MNEs' activities. Int. Bus. Rev. 2014, 23, 966-980. [CrossRef]

60. Waddock, S.-A.; Graves, S.-B. The corporate social performance-Financial performance link. Strat. Manag. J. 1997, 18, 303-320. [CrossRef]

61. Doh, J.-P.; Guay, T.-R. Corporate social responsibility, public policy, and NGO activism in Europe and the United States: An institutional-stakeholder perspective. J. Manag. Stud. 2006, 43, 47-73. [CrossRef]

62. Arenas, D.; Lozano, J.-M.; Albareda, L. The role of NGOs in CSR: Mutual perceptions among stakeholders. J. Bus. Ethic 2009, 88, 175-197. [CrossRef]

63. Imbun, B.-Y. Cannot manage without the 'significant other': Mining, corporate social responsibility and local communities in Papua New Guinea. J. Bus. Ethic 2007, 73, 177-192. [CrossRef] 
64. Ghauri, P.-N.; Cave, A.-H.; Park, B.-I. The impact of foreign parent control mechanisms upon measurements of performance in IJVs in South Korea. Critl. Perspect. Int. Bus. 2013, 9, 251-270. [CrossRef]

65. Zander, U.; Kogut, B. Knowledge and the speed of the transfer and imitation of organizational capabilities: An empirical test. Org. Sci. 1995, 6, 76-92. [CrossRef]

66. Ghana Investment Promotion Centre. Database of Approved Investment Projects; Ghana Investment Promotion Centre: Accra, Ghana, 2018.

67. Furrer, O.; Egri, C.-P.; Ralston, D.-A.; Danis, W.; Reynaud, E.; Naoumova, I.; Molteni, M.; Starkus, A.; Darde, F.L.; Dabic, M.; et al. Attitudes toward corporate responsibilities in Western Europe and in Central and East Europe. Manag. Int. Rev. 2010, 50, 379-398. [CrossRef]

68. Li, S.; Fetscherin, M.; Alon, I.; Lattemann, C.; Yeh, K. Corporate social responsibility in emerging markets: The importance of the governance environment. Manag. Int. Rev. 2010, 50, 635-654. [CrossRef]

69. Mata, J.; Portugal, P. The termination of international joint ventures: Closure and acquisition by domestic and foreign partners. Int. Bus. Rev. 2015, 24, 677-689. [CrossRef]

70. Luo, Y. Political behavior, social responsibility, and perceived corruption: A structuration perspective. J. Int. Bus. Stud. 2006, 37, 747-766. [CrossRef]

71. Podsakoff, P.-M.; MacKenzie, S.-B.; Lee, J.-Y.; Podsakoff, N.-P. Common method biases in behavioral research: A critical review of the literature and recommended remedies. J. Appl. Psych. 2003, 88, 879-903. [CrossRef]

72. Pallant, J. SPSS Survival Manual: A Step by Step Guide to Data Analysis Using SPSS for Windows; Open University Press: Buckingham, Buckinghamshire, UK, 2001.

73. Tabachnick, B.-G.; Fidell, L.-S. Using Multivariate Statistics; Harper Collins: New York, NY, USA, 1996.

74. Hair, J.-J.; Babin, B.; Money, A.-H.; Samouel, P. Essentials of Business Research Methods; Wiley: New York, NY, USA, 2003.

75. Du, S.; Bhattacharya, C.-B.; Sen, S. Maximizing business returns to corporate social responsibility (CSR): The role of CSR communication. Int. J. Manag. Rev. 2010, 12, 8-19. [CrossRef]

76. Amponsah-Tawiah, K.; Dartey-Baah, K. Corporate Social Responsibility in Ghana. Int. J. Bus. Soc. Sci. 2011, 2, 107-112.

77. Anku-Tsede, O.; Deffor, E.-W. Corporate Responsibility in Ghana: An Overview of Aspects of the Regulatory Regime. Bus. Manag. Res. 2014, 3, 31-41. [CrossRef]

78. Williams, P.-A.; Frempong, G.; Akuffobea, M.; Onumah, J. Contributions of multinational enterprises to economic development in Ghana: A myth or reality? Int. J. Develop. Sustainab. 2017, 6, 2068-2081.

79. Sun, H.; Pofoura, A.K.; Mensah, I.A.; Li, L.; Moshin, M. The Role of Environmental Entrepreneurship for Sustainable Development: Evidence from 35 Countries in Sub-Saharan Africa; Elsevier: Amsterdam, The Netherlands, 2020.

80. Sun, Y.; Chen, L.; Sun, H.; Farhad, T. Low-Carbon Financial Risk Factor Correlation in the Belt and Road PPP Project; Elsevier: Amsterdam, The Netherlands, 2020.

81. Fang, T.; Gunterberg, C.; Larsson, E. Sourcing in an increasingly expensive China: Four swedish cases. J. Bus. Ethic 2010, 97, 119-138. [CrossRef]

82. Tian, Z.; Wang, R.; Yang, W. Consumer responses to corporate social responsibility (CSR) in China. J. Bus. Ethic 2011, 101, 197-212. [CrossRef]

83. Munilla, L.-S.; Miles, M.-P. The corporate social responsibility continuum as a component of stakeholder theory. Bus. Soc. Rev. 2005, 110, 371-387. [CrossRef]

84. Qu, R. Effects of government regulations, market orientation and ownership structure on corporate social responsibility in China: An empirical study. Int. J. Manag. 2007, 24, 582-591. 